\title{
Major Reproductive Problems of Dairy Animals under Different Dairy Production Systems
}

\author{
Diksha Patel $^{1 *}$ and K. Ponnusamy ${ }^{2}$ \\ ${ }^{1}$ Agriculture Extension, Krishi Vigyan Kendra, Banda, Banda University of Agriculture and \\ Technology, Banda (Uttar Pradesh), India \\ ${ }^{2}$ Agricultural Extension, Dairy Extension Division, ICAR-National Dairy Research Institute, \\ Karnal (Haryana), India \\ *Corresponding author
}

\section{A B S T R A C T}

\section{Keywords}

Reproductive problems, Dairy production systems, Structured interview schedule,

Constraints

Article Info

Accepted:

12 February 2019

Available Online:

10 March 2019
The present study was undertaken during 2017-18 in Haryana, Madhya Pradesh and Chhattisgarh representing three different dairy production systems namely; dynamic, transient and subsistence dairy production systems of India to assess the prevalence of major reproductive problems of dairy animals and to identify the constraints faced by the farmers in managing reproductive problems. Eighty respondents from each of three states were selected through simple random sampling thus constituting a sample size of 240 . Data were collected through structured interview schedule. Findings revealed that there was high prevalence of anestrus $(19.19 \%)$, repeat breeding $(18.15 \%)$ and prolapse $(15.83$ $\%)$ in dairy animals of Haryana while late sexual maturity $(15.22 \%)$, anestrus $(12.20 \%)$ and repeat breeding $(10.58 \%)$ were reported in Madhya Pradesh. Late sexual maturity $(16.07 \%)$, anestrus $(11.96 \%)$ and RFM $(8.91 \%)$ were important reproductive problems which widely affect the dairy animals in Chhattisgarh. Inadequate veterinary facilities during the time of emergency, high cost of treatment for reproductive problems and lack of knowledge about reproductive management of dairy animals were the most important constraints reported by respondents from Haryana, Madhya Pradesh and Chhattisgarh respectively.

\section{Introduction}

India ranks first in milk production which is mainly ascribed to the large population of low yielding dairy animals not necessarily by the virtue of their milk productivity. The average milk productivity of Indian dairy animal is only $1214 \mathrm{Kg}$ per lactation which is nearly half of the world average of $2104 \mathrm{Kg}$ per lactation (Planning Commission, 2012). The average milk productivity of crossbred cows, indigenous cows and buffaloes is only 7.51, 2.84 and $5.23 \mathrm{~kg} /$ day respectively (BAHFS, 2017). Further, there are wide inter-state and inter-district variations in the milk yield and hence, the yield-gaps even compared to these low- productivity levels are profound. Low milk yield of bovines is mainly attributed to the poor genetic potential, improper breeding management, high incidence of diseases, 
worm infestation and imbalance feeding (Ponnusamy, 2006; Ponnusamy and Ambasankar, 2006).

In India, the milk production has witnessed remarkable progress during last 50 years. The increase in production has been accompanied by increasing incidence of health problems, declining ability to reproduce and declining the fertility of dairy cows. Several studies using field data (Hansen et al., 1983) found unfavourable genetic correlations between milk yield and female fertility traits.

The economic viability of dairy farm mainly depends on reproductive efficiency of its animals. Getting one calf per year should be the goal of any dairy farm in order to harness the maximum profit from their animals. However, this goal is hindered due to reproductive problems especially in female animals which also lead to prolonged inter calving intervals, increased number of insemination for conception, higher culling rates, and thus increased replacement costs. A better comprehension about these reproductive problems and constraints of farmers prevailing in different dairy production systems would help formulating suitable extension strategies and thereby motivating the farmers to adopt appropriate reproductive technologies suitable to field conditions and thus, maximizing reproductive efficiency of the milch bovines. Keeping in view of these facts, the present study was carried out with following objectives:

To assess the prevalence of major reproductive problems of dairy animals under different dairy production systems.

And also to identify the perceived constraints of the farmers in management of reproductive problems of dairy animals under different dairy production systems.

\section{Materials and Methods}

The present study was undertaken during 2017-18. Haryana, Madhya Pradesh and Chhattisgarh were selected representing three different dairy production systems namely; dynamic, transient and subsistence dairy production systems. From each selected state, two districts which were having highest bovine population were selected purposively, as it was presumed that the district with higher bovine population will have highest number of cases of reproductive problems in dairy animals. By this process, two districts namely, Hissar and Bhiwani from Haryana, Rewa and Satna from Madhya Pradesh, and Raipur and Durg from Chhattisgarh, were selected purposively. Eighty respondents from each selected states who were rearing different species of bovines were selected through simple random sampling. Data were collected through structured interview schedule from 240 dairy farmers who had at least one milch animal and also should have at least 5 year of experience in dairying.

For assessing prevalence of reproductive diseases prevalence rate have been calculated. Prevalence rate is operationalized as the ratio of the total number of cases of reproductive problems to the total number of adult milch animal of each respondent during last three years.

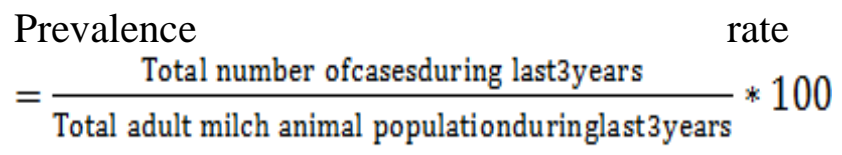

A list of constraints was prepared through literature review and discussion with experts of related field and constraints analysis was done by using weighted mean score method and ranking was also given, based on value of weighted mean score. 
$\overline{\mathrm{X}}=\frac{\sum_{\mathrm{i}=1} \mathrm{X}_{\mathrm{i}} \mathrm{W}_{\mathrm{i}}}{\sum_{\mathrm{i}} \mathrm{W}_{\mathrm{i}}}$

where,,$\frac{\bar{x}}{,}$ weighted mean score

$\mathrm{Xi}$, value of $\mathrm{i}^{\mathrm{th}}$ constraint

$\mathrm{Wi}$, weight of the $i^{\text {th }}$ constraint

\section{Results and Discussion}

Prevalence of reproductive problems in dairy animals under different dairy production systems

For assessing prevalence of reproductive problems, 80 respondents from each selected states who were rearing dairy animals were personally interviewed and their overall prevalence of reproductive problems has been assessed through determining prevalence rate. The data on prevalence of reproductive problems in dairy animals were presented in Table 1. The results shows that the overall prevalence of anestrus (19.19\%), repeat breeding (18.15\%), prolapse $(15.83 \%)$, retention of foetal membrane $(11.96 \%)$, late sexual maturity $(11.37 \%)$, dystocia $(9.37 \%)$, abortion $(4.85 \%)$ and stillbirth $(2.85 \%)$ were main reproductive problems in dairy animals of Hissar and Bhiwani districts of Haryana. A number of factors could be attributed for the cause of repeat breeding such as climatic condition of the area, sub fertile bulls, endocrine imbalance, reproductive tract infections, communal use of bull for natural service and other managerial factors (Arthur et al, 1989).

The data depicted in Table 1 indicates that late sexual maturity was most prevalent reproductive problem in dairy animals of Satna and Rewa districts of Madhya Pradesh with prevalence rate of 15.59 per cent. This might be due to their feeding pattern to animals. Respondents were not providing adequate quantity of green fodder and concentrate to animals. In addition, others practices like deworming and feeding mineral mixture were not adopted by majority of farmers in study area. Heifers were not fed with balanced feed until they start lactating. The animals were also found having anestrus $(12.20 \%)$ followed by repeat breeding (10.58\%), dystocia (7.08\%), RFM (6.84\%), abortion $(4.40 \%)$, prolapse $(4.81 \%)$, abortion $(4.70 \%)$ and stillbirth (4.02\%). The high prevalence of repeat breeding might also be attributed to engaging para-vet or private practitioner for artificial insemination (AI) who does not have adequate experience and expertise. The prevalence of anestrus was also high as mostly respondents observe heat by bellowing method and buffalo was usually observed with silent heat so the farmers find difficulty to detect heat in buffalo.

Late sexual maturity, anestrus and RFM were the major prevalent reproductive problems which affect 16.07 per cent 11.96 per cent and 8.91 per cent of dairy animal population of Raipur and Drug districts of Chhattisgarh respectively. It may be due to the fact that farmers were economically backward and did not have adequate knowledge about scientific dairy farming practices. Feeding of mineral mixture and concentrate was not commonly practiced, that could one of the causes of late onset of maturity as well as anestrus.

Perceived constraints of farmers in management of reproductive problems of dairy animals

The constraints of farmers were mentioned in Table 2. The weighted mean score was calculated and the constraints were ranked accordingly. Poor veterinary facilities during emergency hours (33.83), reduced conception rate due to reproductive disorder in animals (33.50) and economic loss due to decreased reproductive efficiency after occurrence of any reproductive diseases (32.83) were ranked first, second and third constraints respectively in Haryana state. It is generally 
seen that most of the veterinary surgeons/ doctors avoid staying at village level. Due to lack of infrastructure facilities in rural areas, they generally prefer to live in nearby cities. Thereby they might not be available at time of emergency hours. Farmers also perceived that conception rate is reduced to some extent after the occurrence of any reproductive problems in animal. Being origin tract of Murrah buffaloes, dairying is recognized as an important economic activity by farmers in Haryana.

Occurrence of these problems could lead to direct (loss of animal or calf) or indirect (losses due to reduction in milk production, higher calving interval, long service period, late onset of post-partum estrus etc.) economic loss to the farmers. These losses were further enhanced by other interlinked disorders. The prevailing veterinary infrastructure should be effectively harnessed to address the reported reproductive problems of dairy animals.

In case of Madhya Pradesh, high cost of treatment of reproductive disorders was given the first rank with weighted mean score of 34.33 followed by lack of knowledge about reproductive management of dairy animals (33.50) and poor conception rate with AI in dairy animals (31.67). In Chhattisgarh,lack of knowledge about reproductive management of dairy animals (34.17), high cost of treatment of reproductive disorders (34.00) and lack of demand driven development programmes/policy/support/ incentives for reproductive management of dairy animals were found to be first, second and third major constraints respectively.

The present finding are in line with finding reported by Meena et al., (2015) who revealed that inadequate access to A.I. facilities at the village, poor conception rate with A.I. in dairy animals, lack of awareness of farmers about various reproductive stages of dairy animals, lack of knowledge about silent heat and balanced feeding, were the serious constraints faced by farmers in Faizabad district of Uttar Pradesh.

Table.1 Prevalence of reproductive problems in dairy animals under different dairy production systems (in percentage)

\begin{tabular}{|l|l|c|c|c|}
\hline $\begin{array}{l}\text { S. } \\
\text { No. }\end{array}$ & Reproductive problems & $\begin{array}{c}\text { Haryana } \\
(\mathbf{n = 5 6 8})\end{array}$ & $\begin{array}{c}\text { Madhya Pradesh } \\
(\mathbf{n = 4 5 9})\end{array}$ & $\begin{array}{c}\text { Chhattisgarh } \\
(\mathbf{n = 3 0 5})\end{array}$ \\
\hline $\mathbf{1}$ & Late sexual maturity & 11.37 & 15.22 & 16.07 \\
\hline $\mathbf{2}$ & Anestrus & 19.19 & 12.20 & 11.96 \\
\hline $\mathbf{3}$ & Repeat breeding & 18.15 & 10.58 & 8.40 \\
\hline $\mathbf{4}$ & Dystocia & 9.37 & 7.08 & 6.47 \\
\hline $\mathbf{5}$ & Abortion & 4.85 & 4.70 & 8.12 \\
\hline $\mathbf{6}$ & Retention of fetal membrane & 11.96 & 6.84 & 8.91 \\
\hline $\mathbf{7}$ & Stillbirth & 2.85 & 4.02 & 2.50 \\
\hline $\mathbf{8}$ & Prolapse & 15.83 & 4.81 & 4.54 \\
\hline
\end{tabular}

(n represents total number of adult milch animals with respondents during last 3 years) 
Table.2 Perceived constraints of farmers in management of reproductive problems

\begin{tabular}{|c|c|c|c|c|c|c|c|}
\hline S. No. & Constraints of farmers & $\begin{array}{c}\text { Haryana } \\
(\mathrm{n}=\mathbf{8 0})\end{array}$ & Rank & $\begin{array}{c}\text { Madhya } \\
\text { Pradesh }(n=80)\end{array}$ & Rank & $\begin{array}{l}\text { Chhattisgarh } \\
\qquad(\mathrm{n}=\mathbf{8 0})\end{array}$ & Rank \\
\hline 1 & Non availability of AI and PD services at door step & 29.83 & 10 & 26.50 & 11 & 24.67 & 11 \\
\hline 2 & $\begin{array}{l}\text { Lack of trained professionals for AI as well as for } \\
\text { handling of reproductive problems in the locality }\end{array}$ & 31.00 & 5 & 29.83 & 10 & 25.83 & 10 \\
\hline 3 & Poor conception rate with AI in dairy animals & 29.33 & 8 & 31.67 & 3 & 26.00 & 8 \\
\hline 4 & $\begin{array}{l}\text { Economic loss due to decreased reproductive efficiency } \\
\text { after occurrence of any reproductive diseases }\end{array}$ & 32.83 & 3 & 31.00 & 6 & 29.83 & 7 \\
\hline 5 & Poor Veterinary facilities during emergency hours & 33.83 & 1 & 30.17 & 8 & 32.00 & 4 \\
\hline 6 & $\begin{array}{l}\text { Lack of opportunities to access knowledge about } \\
\text { reproductive management of dairy animals }\end{array}$ & 32.33 & 4 & 33.50 & 2 & 34.17 & 1 \\
\hline 7 & $\begin{array}{l}\text { Reduced conception rate due to reproductive disorders in } \\
\text { animals }\end{array}$ & 33.50 & 2 & 30.33 & 7 & 30.67 & 5 \\
\hline 8 & High cost of treatment of reproductive disorders & 31.00 & 5 & 34.33 & 1 & 34.00 & 2 \\
\hline 9 & Non-availability of pasture or grazing land in village & 29.00 & 7 & 30.67 & 9 & 25.67 & 9 \\
\hline 10 & $\begin{array}{l}\text { Less scope for availability of green fodder throughout } \\
\text { year }\end{array}$ & 30.50 & 6 & 31.17 & 5 & 30.50 & 6 \\
\hline 11 & $\begin{array}{l}\text { Lack of demand driven development } \\
\text { programmes/policy/support/ incentives for } \\
\text { management of dairy animals }\end{array}$ & 28.67 & 9 & 31.83 & 4 & 33.00 & 3 \\
\hline
\end{tabular}


The present study concludes that reproductive problems among dairy animals cause significant economic losses to farmers. The study also highlighted the difference between the three geographically and economically different states corresponding to different dairy production systems having varying level of reproductive problems among dairy animals which warrant location specific extension strategies to address the reported problems. Therefore, extension strategies should be realigned in the context of prevailing reproductive problems and localised constraints in managing these reported reproductive problems of dairy animals by farmers. Development of appropriate extension literature, organising fertility camps, educating farmers especially women and youth about reproductive problems and their management through training and exposure visit and effective use of mass media in the localities would provide needed solutions which ultimately lead to health animals producing quality milk.

\section{References}

Arthur, G.H. (1975). Veterinary reproduction and obstetrics. The Macmillan Publishing Company Inc. New York. 4th Ed.: 383-446.

BAHFS.(2017). Basic Animal Husbandry \&
Fisheries statistics. Department of Animal Husbandry Dairying and Fisheries. Ministry of Agriculture. Government of India. New Delhi.

Hansen L. B., Freeman, A. E. and Berger, P. J. (1983).Association of heifer fertility with cow fertility and yield in dairy cattle. Journal of Dairy Science. 66: 306-314.

Meena, B.S., Verma, H.C., Meena, H.R., Singh, A. and Meena, D.K. (2015). Field level study on productive and reproductive parameters of dairy animals in Uttar Pradesh, India. Indian Journal of Animal Research. 49(1): $118-122$

Planning Commission, (2012).Report of working group on Animal Husbandry and Dairying (2007-2012). $11^{\text {th }}$ Five Year Plan, planning Commission, Government of India, New Delhi.

Ponnusamy, K. (2006). Multidimensional analysis of integrated farming system in the coastal agro-ecosystem in Tamil Nadu. Ph.D. Thesis. NDRI, Karnal, Haryana.

Poonusamy, K. and Amarsankar, K. (2006). Technological intervention for socioeconomic enrichment of dairy farmers. Indian Journal of Dairy Science. 59(1): 33-36.

\section{How to cite this article:}

Diksha Patel and Ponnusamy, K. 2019. Major Reproductive Problems of Dairy Animals under Different Dairy Production Systems. Int.J.Curr.Microbiol.App.Sci. 8(03): 1269-1274. doi: https://doi.org/10.20546/ijcmas.2019.803.150 